\title{
Vitamin D and the Risk of Non-Melanoma Skin Cancer: A Systematic Literature Review and Meta-Analysis on Behalf of the Italian Melanoma Intergroup
}

\author{
Saverio Caini ${ }^{1, *(\mathbb{D}}$, Patrizia Gnagnarella ${ }^{2}(0)$, Ignazio Stanganelli ${ }^{3,4}$, Federica Bellerba $^{5}$, Emilia Cocorocchio ${ }^{6}$, \\ Paola Queirolo ${ }^{6}$, Benedetta Bendinelli ${ }^{1}$, Calogero Saieva ${ }^{1}\left(\mathbb{D}\right.$, Sara Raimondi ${ }^{5}$ and Sara Gandini ${ }^{5}(\mathbb{D})$ \\ 1 Institute for Cancer Research, Prevention and Clinical Network (ISPRO), 50139 Florence, Italy; \\ b.bendinelli@ispro.toscana.it (B.B.); c.saieva@ispro.toscana.it (C.S.) \\ 2 Division of Epidemiology and Biostatistics, European Institute of Oncology (IEO), IRCCS, 20141 Milan, Italy; \\ patrizia.gnagnarella@ieo.it \\ 3 Skin Cancer Unit, Istituto Scientifico Romagnolo per lo Studio e la Cura dei Tumori (IRST), IRCCS, \\ 47014 Meldola, Italy; ignazio.stanganelli@irst.emr.it \\ 4 Department of Medicine and Surgery, University of Parma, 43121 Parma, Italy \\ 5 Department of Experimental Oncology, European Institute of Oncology (IEO), IRCCS, 20141 Milan, Italy; \\ Federica.Bellerba@ieo.it (F.B.); sara.raimondi@ieo.it (S.R.); sara.gandini@ieo.it (S.G.) \\ 6 Division of Melanoma Surgery, Sarcoma and Rare Tumours, European Institute of Oncology (IEO), IRCCS, \\ 20141 Milan, Italy; emilia.cocorocchio@ieo.it (E.C.); paola.queirolo@ieo.it (P.Q.)

Citation: Caini, S.; Gnagnarella, P.; Stanganelli, I.; Bellerba, F.; Cocorocchio, E.; Queirolo, P.; Bendinelli, B.; Saieva, C.; Raimondi, S.; Gandini, S. Vitamin D and the Risk of Non-Melanoma Skin Cancer: A Systematic Literature Review and Meta-Analysis on Behalf of the Italian Melanoma Intergroup. Cancers 2021, 13, 4815. https://doi.org/10.3390/ cancers13194815

Academic Editor: Rachel Neale

Received: 24 August 2021

Accepted: 23 September 2021

Published: 26 September 2021

Publisher's Note: MDPI stays neutral with regard to jurisdictional claims in published maps and institutional affiliations.

Copyright: (c) 2021 by the authors Licensee MDPI, Basel, Switzerland. This article is an open access article distributed under the terms and conditions of the Creative Commons Attribution (CC BY) license (https:// creativecommons.org/licenses/by/ $4.0 /)$.
Simple Summary: Vitamin D has been extensively studied in relation to cancer risk at several body sites, but its relationship with non-melanoma skin cancer (NMSC), the most frequent malignancy in humans, is still unclear. Here, we performed a systematic literature search and meta-analysis of published studies and did not find convincing evidence that a causal association exists between vitamin D intake (from foods and supplements), vitamin D blood concentration, or polymorphisms of the genes coding for the vitamin D receptor and binding protein, and NMSC risk.

Abstract: We aimed to provide a comprehensive overview of the link between vitamin $\mathrm{D}$ and non-melanoma skin cancer (NMSC). For this purpose, we conducted a systematic literature review (updated to 3 February 2021) and meta-analysis of the studies reporting on the association between vitamin $\mathrm{D}$ intake (from diet and supplements) and blood concentration, polymorphisms of the vitamin $\mathrm{D}$ receptor $(V D R)$ and vitamin $\mathrm{D}$ binding protein $(V D B P)$ genes, and the risk of NMSC. Random effects meta-analysis models were fitted to merge study-specific risk estimates into summary relative risk (SRR) and corresponding 95\% confidence intervals (CI). Twenty-four studies altogether were included. There was a suggestive association between increasing serum/plasma vitamin D concentration and NMSC risk (SRR for highest vs. lowest concentration 1.67, 95\%CI 0.61-4.56), although with large heterogeneity across studies $\left(\mathrm{I}^{2}=91 \%\right)$. NMSC risk was associated with highest vitamin $D$ intake in observational studies but not in clinical trials. Finally, there was no significant association between any polymorphism of the VDR and VDBP genes and NMSC risk. In conclusion, no strong relationship between vitamin D metabolism and NMSC risk appears to exist according to our systematic review and meta-analysis, although some findings are worthy of further investigation.

Keywords: vitamin D; dietary intake; blood concentration; gene polymorphism; vitamin D receptor; vitamin D binding protein; non-melanoma skin cancer; basal cell cancer; squamous cell cancer; risk

\section{Introduction}

Non-melanoma skin cancers (NMSC) are the most common type of skin malignancies among humans (particularly fair-skinned populations of European descent) and its incidence rates have been on the rise globally for decades [1]. The near totality of NMSC 
is represented by keratinocyte skin cancers (KSC), e.g., basal cell cancer (BCC) and squamous cell cancer (SCC), while other non-melanoma skin cancer types not originating from keratinocytes (e.g., Merkel cell carcinoma) are rare. The economic costs required by the management of NMSC patients are substantial because of very high NMSC incidence rates [2]. The most important environmental risk factor for NMSC is exposure of the skin to ultraviolet radiation (UV) [3]. Other established and suspected risk factors include older age, male sex, light-coloured skin, eyes and hair, use of photosensitizing medications, and having had a previous NMSC diagnosis [4,5]. Given the high NMSC disease burden, research has largely focused on identifying other preventable risk factors, and several publications have examined the role of vitamin D in the aetiology of NMSC.

Vitamin D is produced in human skin and is also found naturally in some foods [6]. In addition, vitamin D-fortified foods are available on the market, and vitamin D can be obtained by taking supplements. In the body, vitamin $\mathrm{D}$ is hydroxylated first in the liver to form 25-hydroxivitamin $\mathrm{D}[25(\mathrm{OH}) \mathrm{D}]$, which is the major circulating form of vitamin $\mathrm{D}$, and then in the kidney to form the physiologically active 1,25-dihydroxyvitamin D. Most vitamin $\mathrm{D}$ in the blood is bound to the vitamin $\mathrm{D}$ binding protein (VDBP). To exert its action, calcitriol binds to the vitamin $\mathrm{D}$ receptor (VDR): several polymorphisms of the VDR gene lead to an altered functionality of the VDR protein, and have been investigated in association with the occurrence of several diseases.

The best defined role of vitamin $\mathrm{D}$ in humans is in supporting the normal development and maintenance of bone tissues and in regulating calcium metabolism $[7,8]$. Furthermore, there is growing evidence that vitamin D plays a role in many fundamental biological processes (e.g., cell proliferation, angiogenesis, and modulation of the immune system) [9] implicated in carcinogenesis. Several papers have been published in recent years on the link between vitamin D and NMSC risk, but results are mostly conflicting. In order to provide the most comprehensive overview possible on this topic, we conducted a systematic review and meta-analysis of studies that reported on the association between vitamin D blood concentration and intake (from food and/or supplements), and polymorphisms of $V D R$ and $V D B P$ genes, and NMSC risk.

\section{Results}

The literature search yielded 4232 non-duplicate entries, of which 4026 were removed based on title (Figure 1). The remaining 206 articles were read in full text, and 182 were removed based on the predefined exclusion criteria, leaving a total of 24 articles. No additional articles were identified by means of backward citation chaining. The study quality was deemed as fair or good for the majority of studies (File S1); the most common potential sources of bias were the non-representativeness of study populations, the failure to adjust for potential confounders, and the lack of information on study subjects lost to follow-up.

\subsection{Vitamin D Blood Concentration and NMSC Risk}

Ten studies reported a RR estimate comparing NMSC risk among those in the highest vs. lowest category of serum/plasma 25(OH)D concentration (Table 1) [10-19]. Of these, five were conducted in the USA, two in Denmark, and one each in Australia, Brazil, and Poland. In terms of study design, three were case-control studies $[13,17,19]$, two were nested case-control studies $[10,11]$, and five were cohort studies $[12,14-16,18]$. The ten studies encompassed a total of 3899 NMSC cases, of which $1569(40.2 \%)$ were contributed by Winsløw et al. [18]. Vitamin D concentration was measured in serum in all studies except in Liang et al. [14]. The studies differed greatly both in the categories that were used to calculate the RR for the highest vs. lowest vitamin D concentration comparison, and in the degree of statistical adjustment. In particular, for three studies an unadjusted OR was calculated using data provided in the paper $[13,17,19]$. In random effects meta-analysis, there was a non-significant $67 \%$ increase in NMSC risk among those in the highest vs. lowest category of $25(\mathrm{OH}) \mathrm{D}$ concentration (95\%CI 0.61-4.56) (Figure 2), with very large heterogeneity of RR estimates across studies $\left(\mathrm{I}^{2}=91 \%\right)$. No indication for publication bias 
was found ( $p=0.11$ ) and meta-regression did not indicate any significant factor associated with heterogeneity (type of cancer $p=0.47$, study design $p=0.16$ ).

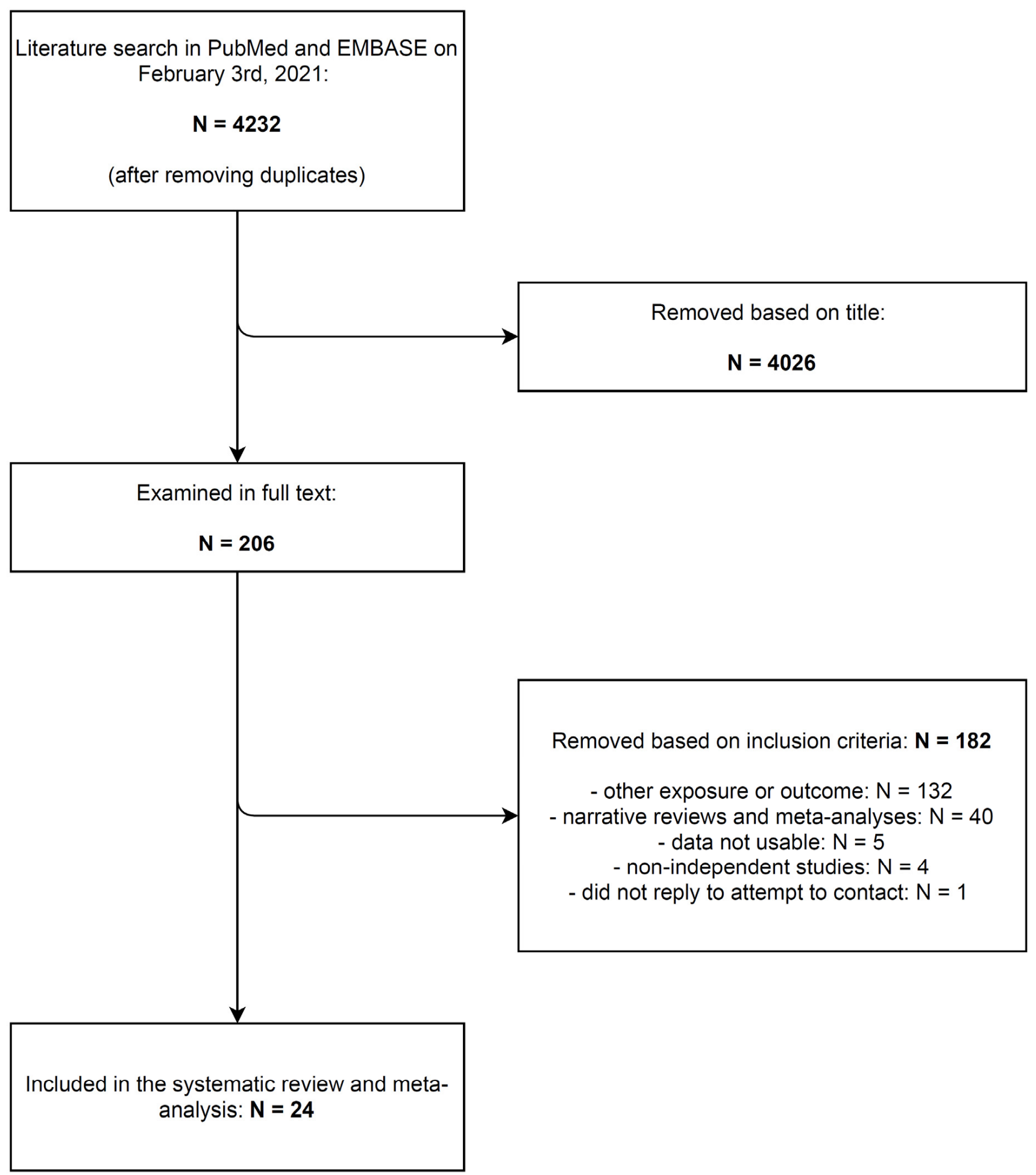

Figure 1. Article selection for the systematic review and meta-analysis on the association between vitamin $\mathrm{D}$ receptor (VDR) and vitamin D binding protein (VDBP) genes polymorphisms, vitamin D blood concentration, and vitamin D dietary intake and supplements use, and non-melanoma skin cancer risk. 
Table 1. Main characteristics of the studies reporting on the association between serum/plasma concentration of $25(\mathrm{OH}) \mathrm{D}$ (comparison: highest vs. lowest category) and the risk of non-melanoma skin cancer.

\begin{tabular}{|c|c|c|c|c|c|c|c|c|c|c|c|c|c|}
\hline $\begin{array}{l}\text { Author, } \\
\text { Year }\end{array}$ & Country & $\begin{array}{l}\text { Study } \\
\text { Design }\end{array}$ & $\begin{array}{l}\text { Skin } \\
\text { Cancer } \\
\text { Type }\end{array}$ & $\begin{array}{c}\mathbf{N} \\
\text { Cases }\end{array}$ & $\begin{array}{l}\text { N Con- } \\
\text { trols/Cohort } \\
\text { Size }\end{array}$ & $\begin{array}{c}\% \\
\text { Males }\end{array}$ & $\begin{array}{c}\text { Age at } \\
\text { NMSC } \\
\text { (yrs) }\end{array}$ & $\begin{array}{c}\text { Years of } \\
\text { Diagnosis }\end{array}$ & Exposure & Comparison & $\mathbf{R R}$ & $95 \% \mathrm{CI}$ & Adjusting Variables \\
\hline $\begin{array}{l}\text { Asgari, } \\
2010[10]\end{array}$ & USA & NCC & $\mathrm{BCC}$ & 220 & 220 & $51.8 \%$ & $\begin{array}{c}\text { mean } 54.9, \\
\text { range } \\
28-78\end{array}$ & 1968-1989 & $\begin{array}{l}\text { serum } \\
25(\mathrm{OH}) \mathrm{D}\end{array}$ & $\begin{array}{c}\text { 5th vs. 1st quintile } \\
\quad(>29.8 \mathrm{vs} \text {. } \\
<14.7 \mathrm{ng} / \mathrm{mL})\end{array}$ & 2.09 & $0.95-4.58$ & $\begin{array}{l}\text { age, sex, season of } \\
\text { sampling, phenotype, } \\
\text { UV exposure, other }\end{array}$ \\
\hline $\begin{array}{l}\text { Skelsey, } \\
\text { 2010 [19] } \\
\text { (a) (b) }\end{array}$ & USA & $\mathrm{CC}$ & KSC & 50 & 14 & ns & $\begin{array}{l}\text { range } \\
18-65\end{array}$ & ns & $\begin{array}{l}\text { serum } \\
25(\mathrm{OH}) \mathrm{D}\end{array}$ & $\geq 30$ vs. $<30 \mathrm{ng} / \mathrm{ml}$ & 0.16 & $0.004-1.30$ & none ${ }^{(c)}$ \\
\hline $\begin{array}{l}\text { Tang, } 2010 \\
\text { [11] }\end{array}$ & USA & NCC & NMSC & 178 & 930 & $100.0 \%$ & mean 73.6 & 2000-2007 & $\begin{array}{l}\text { serum } \\
25(\mathrm{OH}) \mathrm{D}\end{array}$ & $\begin{array}{c}\text { 5th vs. 1st quintile } \\
(\geq 29.9 \text { vs. }<16 \mathrm{ng} / \mathrm{mL})\end{array}$ & 0.54 & $0.31-0.96$ & $\begin{array}{l}\text { age, season of } \\
\text { sampling, other }\end{array}$ \\
\hline $\begin{array}{l}\text { Eide, } 2011 \\
\quad[12]\end{array}$ & USA & cohort & KSC & 240 & 3223 & $10.7 \%$ & ns & 1997-2009 & $\begin{array}{l}\text { serum } \\
25(\mathrm{OH}) \mathrm{D}\end{array}$ & $\begin{array}{l}\text { 4th vs. 1st quartile } \\
\text { ( } \geq 31 \mathrm{vs.}<19 \mathrm{ng} / \mathrm{mL})\end{array}$ & 1.6 & $1.1-2.3$ & age, sex \\
\hline $\begin{array}{l}\text { Lesiak, } \\
2011[13]\end{array}$ & Poland & $\mathrm{CC}$ & $\mathrm{BCC}$ & 142 & 142 & $50.0 \%$ & $\begin{array}{l}\text { mean } 56, \\
\text { range } \\
45-78\end{array}$ & 2007-2008 & $\begin{array}{l}\text { serum } \\
25(\mathrm{OH}) \mathrm{D}\end{array}$ & $>30$ vs. $<20 \mathrm{ng} / \mathrm{ml}$ & 0.18 & $0.08-0.37$ & none ${ }^{(c)}$ \\
\hline $\begin{array}{l}\text { Liang, } 2012 \\
\quad[14]\end{array}$ & USA & cohort & $\begin{array}{l}\mathrm{BCC} \\
\mathrm{SCC}\end{array}$ & $\begin{array}{l}510 \\
75\end{array}$ & 4641 & $0.0 \%$ & ns & 1976-2008 & $\begin{array}{l}\text { plasma } \\
25(\mathrm{OH}) \mathrm{D}\end{array}$ & 4th vs. 1st quartile & $\begin{array}{l}2.07 \\
3.77\end{array}$ & $\begin{array}{l}1.52-2.80 \\
1.70-8.36\end{array}$ & $\begin{array}{l}\text { age, season of } \\
\text { sampling, UV } \\
\text { exposure, phenotype, } \\
\text { phototype, other }\end{array}$ \\
\hline $\begin{array}{c}\text { van der } \\
\text { Pols, 2013 } \\
{[15]}\end{array}$ & Australia & cohort & $\begin{array}{l}\mathrm{BCC} \\
\mathrm{SCC}\end{array}$ & $\begin{array}{l}300 \\
176\end{array}$ & 1191 & $\begin{array}{l}50.0 \% \\
56.0 \%\end{array}$ & $\begin{array}{l}\text { mean } 58 \\
\text { mean } 63\end{array}$ & 1996-2007 & $\begin{array}{l}\text { serum } \\
25(\mathrm{OH}) \mathrm{D}\end{array}$ & $\begin{array}{l}\geq 75 \text { vs. }<75 \mathrm{nmol} / \mathrm{L} \\
\geq 75 \text { vs. }<75 \mathrm{nmol} / \mathrm{L}\end{array}$ & $\begin{array}{l}1.51 \\
0.67\end{array}$ & $\begin{array}{l}1.10-2.07 \\
0.44-1.03\end{array}$ & $\begin{array}{l}\text { age, sex, UV exposure, } \\
\text { phenotype, phototype, } \\
\text { other }\end{array}$ \\
\hline $\begin{array}{l}\text { Skaaby, } \\
2014[16]\end{array}$ & Denmark & cohort & NMSC & 398 & 12,204 & $48.1 \%$ & ns & 1993-2011 & $\begin{array}{c}\text { serum } \\
25(\mathrm{OH}) \mathrm{D}\end{array}$ & 4th vs. 1st quartile & 1.43 & $1.05-1.93$ & $\begin{array}{l}\text { age, sex, season of } \\
\text { sampling, other }\end{array}$ \\
\hline $\begin{array}{l}\text { Soares, } \\
2018[17] \\
\text { (b) }\end{array}$ & Brazil & $\mathrm{CC}$ & $\mathrm{KSC}$ & 41 & 200 & $56.1 \%$ & $\begin{array}{l}\text { mean } 67, \\
\text { range } \\
21-87\end{array}$ & 2016-2017 & $\begin{array}{l}\text { serum } \\
25(\mathrm{OH}) \mathrm{D}\end{array}$ & $\geq 30 \mathrm{vs.}<20 \mathrm{ng} / \mathrm{ml}$ & 50.00 & $11.11-100.0$ & none ${ }^{(c)}$ \\
\hline $\begin{array}{l}\text { Winsløw, } \\
2018[18]\end{array}$ & Denmark & cohort & NMSC & 1569 & 35,298 & $43.0 \%$ & ns & 1981-2012 & $\begin{array}{l}\text { plasma } \\
25(\mathrm{OH}) \mathrm{D}\end{array}$ & $\geq 50$ vs. $<25 \mathrm{nmol} / \mathrm{L}$ & 3.76 & $2.58-5.48$ & $\begin{array}{l}\text { age, sex, season of } \\
\text { sampling, other }\end{array}$ \\
\hline
\end{tabular}

CC: case-control. NCC: nested case-control. BCC: basal cell cancer. SCC: squamous cell cancer. KSC: keratinocyte skin cancer. NMSC: non-melanoma skin cancer. (a) Conference abstract. ${ }^{\text {(b) }}$ RR were inverted (compared to what reported in the text) so that the category of patients with lowest $25(\mathrm{OH}) \mathrm{d}$ concentration is the category of reference. (c) Unadjusted OR calculated using data provided in the contingency table.

Asgari, 2010 BCC

Skelsey, 2010

Tang, 2010

Eide, 2011

Lesiak 2011 BCC

Liang, 2012 BCC

Liang, 2012 SCC

Van der pols, 2013 BCC

Van der pols, 2013 SCC

Skaaby, 2014

Soares, 2018

Winslow, 2018

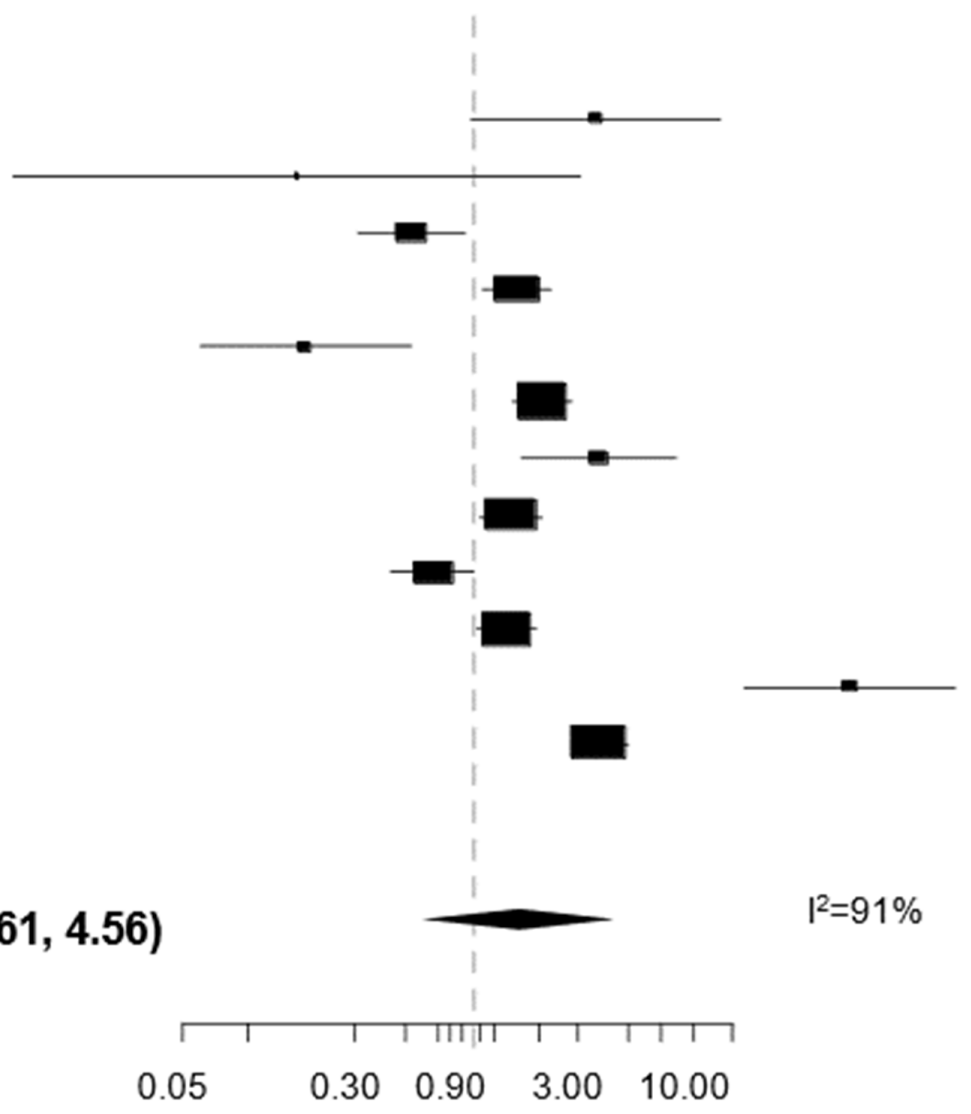

Figure 2. Forest plot for the association between the serum/plasma concentration of 25(OH)D (comparison: highest vs. lowest category) and the risk of non-melanoma skin cancer. BCC: basal cell cancer. SCC: squamous cell cancer. RR: relative risk. 
Two other studies were not included in the meta-analysis because they were based on populations composed of patients. Gruijl et al. detected no association between serum 25(OH)D concentration and SCC risk in a cohort of 1192 kidney transplant patients [20]. Instead, Mansoor et al. found an increased risk of both BCC (OR 2.62, 95\% CI 2.42-2.85) and SCC (OR 2.89, 95\% CI 2.61-3.20) among Crohn's disease patients with vitamin D deficiency [21].

Six independent studies provided a RR estimate for the increase in NMSC risk associated with a linear increment in serum $25(\mathrm{OH}) \mathrm{D}$ concentrations (Table 2). Of these, four were already described in the previous section $[10,15,16,18]$. The remaining two papers were a hospital-based case-control study conducted in Iran enrolling 63 SCC and an equal number of controls and a large Danish cohort $(n=217,244$ and 5045 NMSC cases) [22,23]. The studies differed in several regards, including the linear increment in serum $25(\mathrm{OH}) \mathrm{D}$ that was considered to calculate the RR. Because of this, and since the study by Vojdeman et al. greatly outnumbered the sample size of the other five studies, we did not conduct a formal meta-analysis, as originally planned. Of note, three out of the six studies reported a significant, positive dose-response association between increasing vitamin $\mathrm{D}$ concentration and NMSC risk $[10,18,23]$, and a trend in the same direction emerged in the studies by van der Pols et al. (limitedly to BCC) [14] and Skaaby et al. [16].

Table 2. Main characteristics of the studies reporting on the linear dose-response association between serum/plasma concentration of $25(\mathrm{OH}) \mathrm{D}$ and the risk of non-melanoma skin cancer.

\begin{tabular}{|c|c|c|c|c|c|c|c|c|c|c|c|c|c|}
\hline $\begin{array}{l}\text { Author, } \\
\text { Year }\end{array}$ & Country & $\begin{array}{l}\text { Study } \\
\text { Design }\end{array}$ & $\begin{array}{l}\text { Skin } \\
\text { Cancer } \\
\text { Type }\end{array}$ & $\begin{array}{c}\mathbf{N} \\
\text { Cases }\end{array}$ & $\begin{array}{l}\text { N Con- } \\
\text { trols/Cohort } \\
\text { Size }\end{array}$ & $\begin{array}{c}\% \\
\text { Males }\end{array}$ & $\begin{array}{c}\text { Age at NMSC } \\
\text { (yrs) }\end{array}$ & $\begin{array}{c}\text { Years of } \\
\text { Diagnosis }\end{array}$ & Exposure & Linear Increment By & RR & $95 \% \mathrm{CI}$ & Adjusting Variables \\
\hline $\begin{array}{l}\text { Asgari, } \\
2010[10]\end{array}$ & USA & NCC & BCC & 220 & 220 & $51.8 \%$ & $\begin{array}{l}\text { mean } 54.9, \\
\text { range } 28-78\end{array}$ & 1968-1989 & $\begin{array}{c}\text { serum } \\
25(\mathrm{OH}) \mathrm{D}\end{array}$ & $1 \mathrm{ng} / \mathrm{mL}$ & 1.02 & $1.00-1.05$ & $\begin{array}{l}\text { age, sex, season of } \\
\text { sampling, UV } \\
\text { exposure, other }\end{array}$ \\
\hline \multirow{2}{*}{$\begin{array}{l}\text { van der } \\
\text { Pols, 2013 } \\
\text { [15] }\end{array}$} & \multirow[t]{2}{*}{ Australia } & \multirow[t]{2}{*}{ cohort } & ВСС & 300 & \multirow[t]{2}{*}{1191} & $50.0 \%$ & mean 58 & \multirow[t]{2}{*}{ 1996-2007 } & \multirow{2}{*}{$\begin{array}{l}\text { serum } \\
25(\mathrm{OH}) \mathrm{D} \\
\text { serum } \\
25(\mathrm{OH}) \mathrm{D}\end{array}$} & \multirow[t]{2}{*}{$50 \mathrm{nmol} / \mathrm{L}$} & 1.35 & $0.94-1.93$ & \multirow{2}{*}{$\begin{array}{l}\text { age, sex, phenotype, } \\
\text { phototype, UV } \\
\text { exposure, other }\end{array}$} \\
\hline & & & SCC & 176 & & $56.0 \%$ & mean 63 & & & & 0.68 & $0.42-1.11$ & \\
\hline $\begin{array}{r}\text { Skaaby, } \\
2014[16]\end{array}$ & Denmark & cohort & NMSC & 398 & 12,204 & $48.1 \%$ & ns & 1993-2011 & $\begin{array}{c}\text { serum } \\
25(\mathrm{OH}) \mathrm{D}\end{array}$ & $10 \mathrm{nmol} / \mathrm{L}$ & 1.06 & $0.95-1.17$ & $\begin{array}{l}\text { age, sex, season of } \\
\text { sampling, other }\end{array}$ \\
\hline $\begin{array}{l}\text { Winslow, } \\
2018[18]\end{array}$ & Denmark & cohort & NMSC & 1569 & 35,298 & $43.0 \%$ & ns & 1981-2012 & $\begin{array}{c}\text { plasma } \\
25(\mathrm{OH}) \mathrm{D}\end{array}$ & $20 \mathrm{nmol} / \mathrm{L}$ & 1.13 & $1.10-1.17$ & $\begin{array}{l}\text { age, sex, season of } \\
\text { sampling, other }\end{array}$ \\
\hline $\begin{array}{l}\text { Hosseini, } \\
2019[22]\end{array}$ & Iran & $\mathrm{CC}$ & SCC & 63 & 63 & $79.4 \%$ & $\begin{array}{l}\text { mean } 50.2, \\
\text { range } 19-86\end{array}$ & 2014 & $\begin{array}{l}\text { serum } \\
25(\mathrm{OH}) \mathrm{D}\end{array}$ & $1 \mathrm{nmol} / \mathrm{L}$ & 0.94 & $0.88-1.00$ & $\begin{array}{l}\text { age, sex, UV exposure, } \\
\text { other }\end{array}$ \\
\hline $\begin{array}{l}\text { Vojdeman, } \\
2019 \text { [23] }\end{array}$ & Denmark & cohort & NMSC & 5045 & 217,244 & $34.7 \%$ & ns & 2004-2014 & $\begin{array}{l}\text { serum } \\
25(\mathrm{OH}) \mathrm{D}\end{array}$ & $10 \mathrm{nmol} / \mathrm{L}$ & 1.09 & $1.09-1.10$ & $\begin{array}{l}\text { age, sex, season of } \\
\text { sampling, other }\end{array}$ \\
\hline
\end{tabular}

CC: case-control. NCC: nested case-control. BCC: basal cell cancer. SCC: squamous cell cancer. NMSC: non-melanoma skin cancer.

\subsection{Vitamin D Dietary Intake and Supplements Use and NMSC Risk}

Five studies reported on the association between vitamin D intake (from diet, from supplements, or both) and NMSC risk [24-28] (Table 3). Davies et al. reported a case-control study of 109 BCC cases and 247 controls nested in a population-based UK cohort and found no significant association between vitamin D intake from food and BCC risk [24]. Likewise, no significant association emerged in the population-based case-control study by Asgari et al., which included 415 SCC and an equal number of controls in the USA [25]. Park et al. analyzed data from the Nurses' Health and Health Professionals Follow-up prospective studies and reported an increased risk of BCC (but not SCC) among those in the highest quintile of total vitamin D intake (food + supplements) [26]. Finally, in two RCT, both conducted in the USA, NMSC risk was compared among study participants being given vitamin D supplements and those in the placebo group, but no significant association was found $[27,28]$. We did not calculate a SRR because of the heterogeneity across studies in terms of study design (two RCTS and three observational studies) and type of exposure (vitamin D from food, supplements, or both). 
Table 3. Main characteristics of the studies reporting on the association between vitamin D intake (from foods, supplements, or both) and the risk of non-melanoma skin cancer.

\begin{tabular}{|c|c|c|c|c|c|c|c|c|c|c|c|c|c|}
\hline $\begin{array}{l}\text { Author, } \\
\text { Year }\end{array}$ & Country & $\begin{array}{l}\text { Study } \\
\text { Design }\end{array}$ & $\begin{array}{l}\text { Skin } \\
\text { Cancer } \\
\text { Type }\end{array}$ & $\begin{array}{l}\mathbf{N} \\
\text { Cases }\end{array}$ & $\begin{array}{l}\text { N Con- } \\
\text { trols/Cohort } \\
\text { Size }\end{array}$ & $\begin{array}{c}\% \\
\text { Males } \\
\end{array}$ & $\begin{array}{l}\text { Age at } \\
\text { NMSC } \\
\text { (yrs) }\end{array}$ & $\begin{array}{c}\text { Years of } \\
\text { Diagnosis }\end{array}$ & Exposure & Comparison & RR & $95 \% \mathrm{CI}$ & Adjusting Variables \\
\hline $\begin{array}{l}\text { Davies, } \\
2002[24]\end{array}$ & UK & NCC & BCC & 109 & 247 & $52.3 \%$ & $\begin{array}{l}\text { mean 66, } \\
\text { range } \\
46-79\end{array}$ & 1993-1998 & intake from food & $\begin{array}{c}\text { linear increase } \\
\text { by } \\
2.08 \text { microg } / \mathrm{d}\end{array}$ & 1.07 & $0.84-1.35$ & age, sex, phenotype, other \\
\hline $\begin{array}{l}\text { Asgari, } \\
2011[25]\end{array}$ & USA & $\mathrm{CC}$ & SCC & 415 & 415 & $61.9 \%$ & $\begin{array}{l}\text { mean } 72.5, \\
\text { range } \\
43-85\end{array}$ & 2004 & $\begin{array}{l}\text { supplement use } \\
\geq 3 \text { months in the past } \\
10 \text { years }\end{array}$ & any vs. none & 0.78 & $0.46-1.32$ & age, sex, phenotype, other \\
\hline $\begin{array}{l}\text { Tang, } 2011 \\
{[26]^{\text {(a) }}}\end{array}$ & USA & RCT & NMSC & 3338 & 36,282 & $0.0 \%$ & ns & 1995 & $\begin{array}{l}200 \mathrm{IU} \text { twice daily } \\
\text { (intervention arm) }\end{array}$ & $\begin{array}{l}\text { supplementation } \\
\text { vs. placebo }\end{array}$ & 1.02 & $0.95-1.07$ & age \\
\hline \multirow{2}{*}{$\begin{array}{l}\text { Park, } 2016 \\
{[27]^{(b)}}\end{array}$} & \multirow{2}{*}{ USA } & \multirow{2}{*}{ cohort } & $\mathrm{BCC}$ & 20,840 & \multirow{2}{*}{109,290} & \multirow{2}{*}{$38.0 \%$} & \multirow{2}{*}{ ns } & \multirow{2}{*}{ 1984-2010 } & \multirow{2}{*}{$\begin{array}{l}\text { intake from food }+ \\
\text { supplements }\end{array}$} & \multirow{2}{*}{$\begin{array}{l}\text { 5th vs. 1st } \\
\text { quintile }\end{array}$} & 1.10 & $1.05-1.15$ & \multirow{2}{*}{$\begin{array}{c}\text { age, sex, phenotype, } \\
\text { phototype, UV exposure, } \\
\text { other }\end{array}$} \\
\hline & & & SCC & 2329 & & & & & & & 1.02 & $0.89-1.17$ & \\
\hline $\begin{array}{l}\text { Passarelli, } \\
2020\end{array}$ & USA & RCT & $\begin{array}{l}\text { BCC } \\
\text { SCC }\end{array}$ & $\begin{array}{l}200 \\
68\end{array}$ & 2259 & $63.0 \%$ & ns & 2004-2016 & $\begin{array}{l}1000 \text { IU/day } \\
\text { (intervention arm) }\end{array}$ & $\begin{array}{l}\text { supplementation } \\
\text { vs. placebo }\end{array}$ & $\begin{array}{l}0.96 \\
0.79\end{array}$ & $\begin{array}{l}0.73-1.26 \\
0.49-1.27\end{array}$ & $\begin{array}{l}\text { age, sex, UV exposure, } \\
\text { other }\end{array}$ \\
\hline
\end{tabular}

(a) Participants in the intervention arm received $500 \mathrm{mg}$ of elemental Ca twice daily in addition to vitamin D. (b) Results were also available for vitamin D from foods only, and stratified for the two sub-cohorts (Nurses' Health Study and Health Professionals Follow-up Study).

\subsection{VDR and VDBP Genes Polymorphisms and NMSC Risk}

Five papers reported on the association between any of five polymorphisms of the VDR gene (Apa1, Bsm1, Cdx2, Fok1, and Taq1) and NMSC risk [13,29-32]. The studies were conducted in the USA $(\mathrm{n}=2)$ and Europe $(\mathrm{n}=3)$ (Table 4). Meta-analysis was conducted for three polymorphisms: Apa1, Bsm1, and Taq1: no association with NMSC risk emerged for any of these three polymorphisms, either in the Hom vs. WT or in the Het vs. WT models (Figures 3-5). The heterogeneity was below 50\% for all models. The relationship between $C d x 2$ and Fok1 polymorphism and NMSC risk was examined in the paper by Han et al. [30]: no significant association emerged in any of the models that were fitted. Instead, the Fok1 TT (Hom) genotype was reported to significantly increase BCC risk (OR $=10.14$, $p$-value $<0.001)$ in the study by Lesiak et al. [13].

Table 4. Main characteristics of the studies reporting on the association between polymorphisms of the vitamin D receptor $(V D R)$ gene and the risk of non-melanoma skin cancer.

\begin{tabular}{|c|c|c|c|c|c|c|c|c|c|c|}
\hline \multirow{2}{*}{$\begin{array}{c}\text { Author, } \\
\text { Year }\end{array}$} & \multirow{2}{*}{ Country } & \multirow{2}{*}{$\begin{array}{l}\text { Study } \\
\text { Design }\end{array}$} & \multirow{2}{*}{$\begin{array}{c}\text { Skin } \\
\text { Cancer } \\
\text { Type }\end{array}$} & \multirow{2}{*}{ N Cases } & \multirow{2}{*}{$\begin{array}{c}\mathrm{N} \\
\text { Controls }\end{array}$} & \multicolumn{5}{|c|}{ VDR Polymorphisms } \\
\hline & & & & & & Apa1 & Fok1 & Bsm1 & $C d x 2$ & Taq1 \\
\hline \multirow{2}{*}{$\begin{array}{c}\text { Han, } \\
2007 \text { [30] }\end{array}$} & \multirow{2}{*}{ USA } & \multirow{2}{*}{$\mathrm{NCC}$} & $\mathrm{BCC}$ & 295 & \multirow{2}{*}{853} & & $\mathrm{x}$ & $x$ & $\mathrm{x}$ & \\
\hline & & & SCC & 281 & & & $x$ & $x$ & $\mathrm{x}$ & \\
\hline $\begin{array}{c}\text { Lesiak, } \\
2011 \text { [13] }\end{array}$ & Poland & $\mathrm{hCC}$ & $\mathrm{BCC}$ & 142 & 142 & $\mathrm{x}$ & $\mathrm{x}$ & $x$ & & $\mathrm{x}$ \\
\hline \multirow{2}{*}{$\begin{array}{l}\text { Köstner, } \\
2012 \text { [31] }\end{array}$} & \multirow{2}{*}{ Germany } & \multirow{2}{*}{ hCC } & $\mathrm{BCC}$ & 87 & \multirow{2}{*}{50} & $x$ & & & & $x$ \\
\hline & & & SCC & 100 & & $x$ & & & & $x$ \\
\hline $\begin{array}{c}\text { Burns, } \\
2017 \text { [29] }\end{array}$ & USA & $\mathrm{hCC}$ & KSC & 97 & 100 & $\mathrm{x}$ & & $\mathrm{x}$ & & $x$ \\
\hline \multirow{2}{*}{$\begin{array}{l}\text { Morgado- } \\
\text { Águila, } \\
2020 \text { [32] }\end{array}$} & \multirow{2}{*}{ Spain } & \multirow{2}{*}{$\mathrm{hCC}$} & BCC & 61 & \multirow{2}{*}{73} & $x$ & & $x$ & & \\
\hline & & & SCC & 20 & & $x$ & & $x$ & & \\
\hline
\end{tabular}

BCC: basal cell cancer. SCC: squamous cell cancer. KSC: keratinocyte skin cancer. NMSC: non-melanoma skin cancer. NCC: nested case-control study. hCC: hospital-based case-control study. 

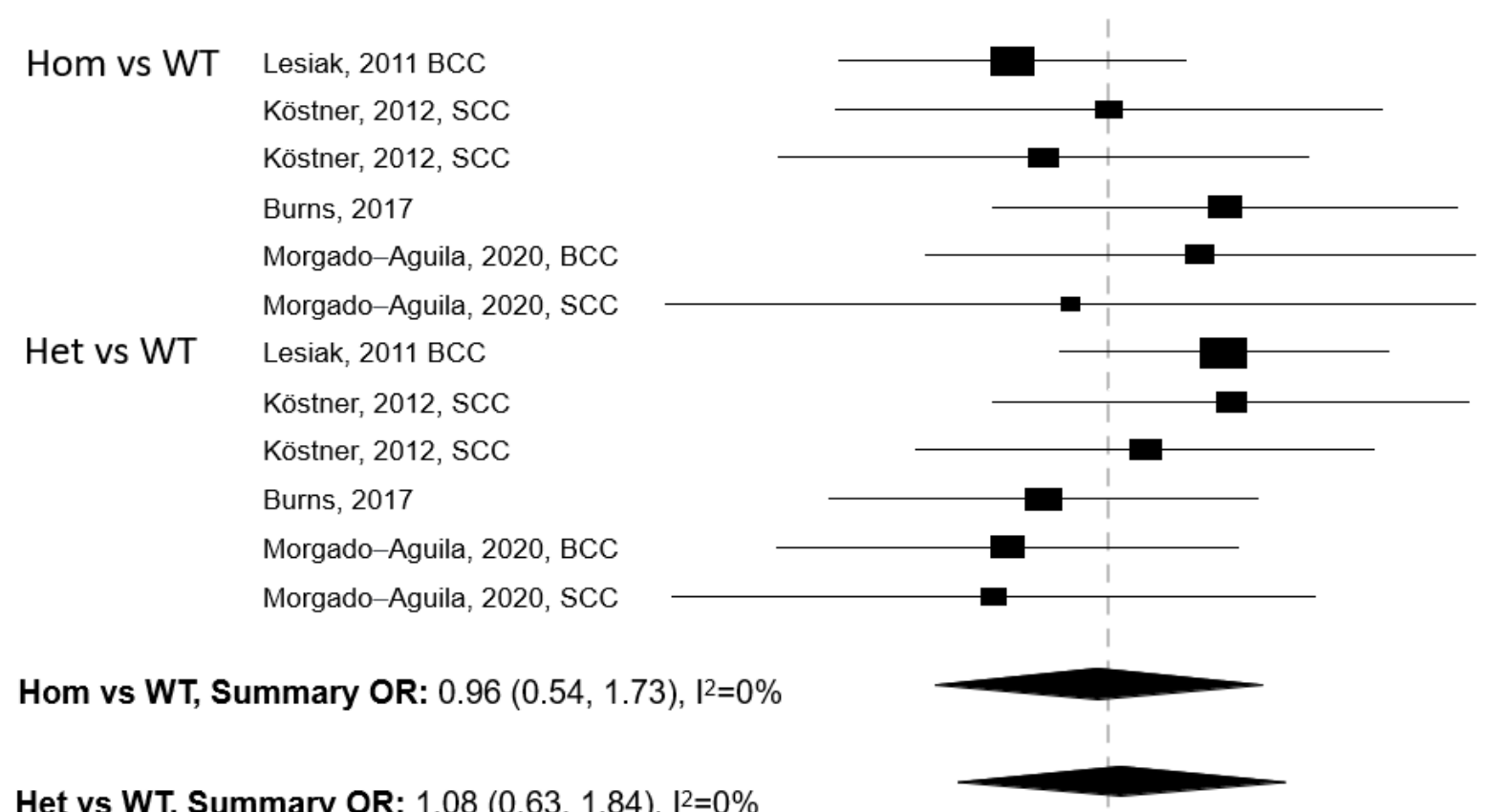

Het vs WT, Summary OR: $1.08(0.63,1.84), l^{2}=0 \%$

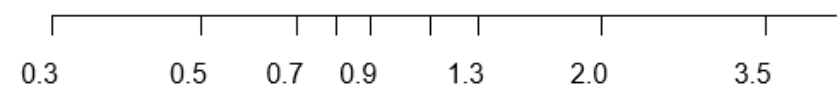

Figure 3. Forest plot for the association between the Apa1 polymorphism of the vitamin D receptor (VDR) gene and the risk of non-melanoma skin cancer. BCC: basal cell cancer. SCC: squamous cell cancer. RR: relative risk. Hom: homozygous. Het: heterozygous. WT: wild-type.

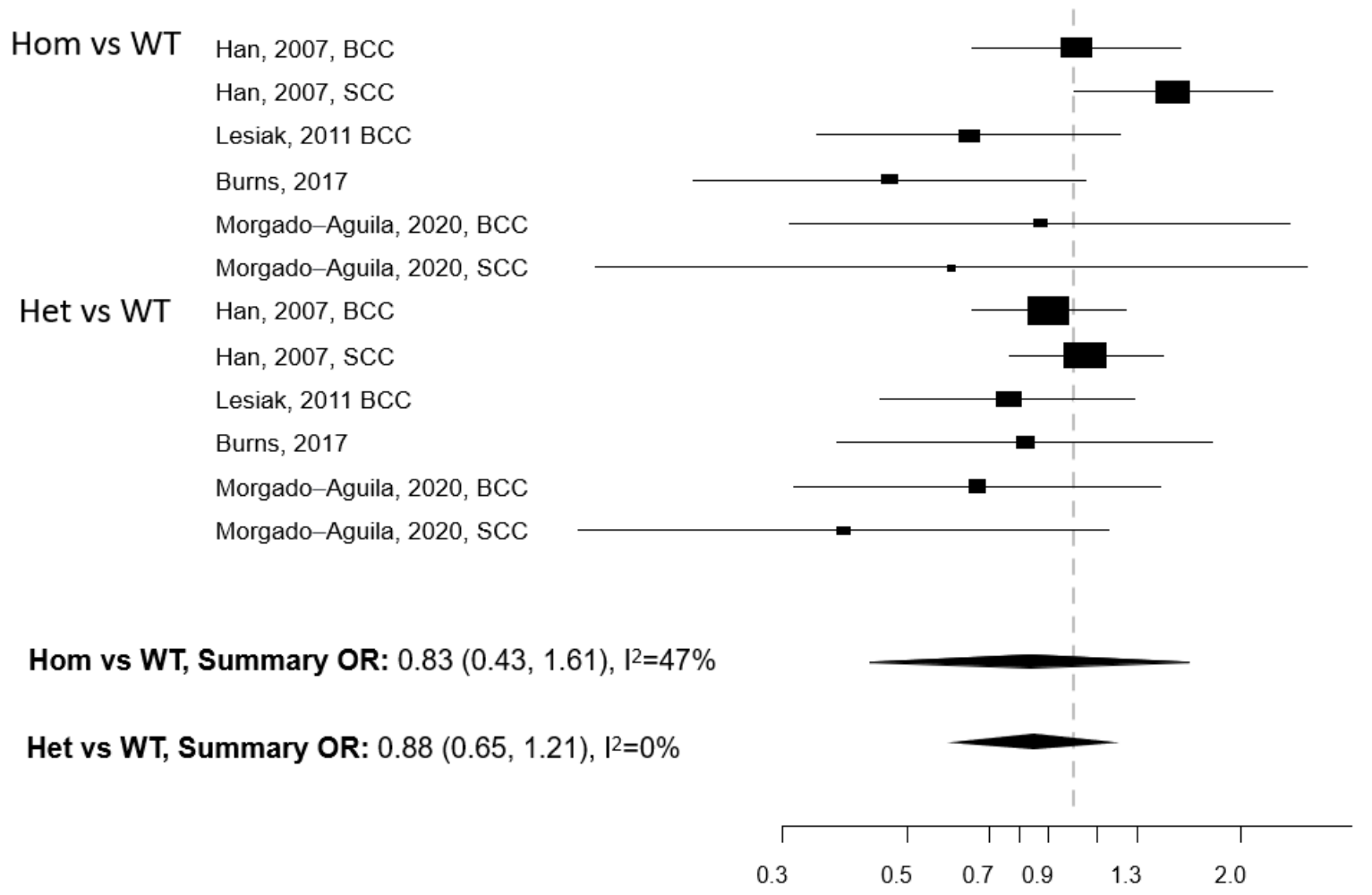

Figure 4. Forest plot for the association between the $B s m 1$ polymorphism of the vitamin $\mathrm{D}$ receptor (VDR) gene and the risk of non-melanoma skin cancer. BCC: basal cell cancer. SCC: squamous cell cancer. RR: relative risk. Hom: homozygous. Het: heterozygous. WT: wild-type. 


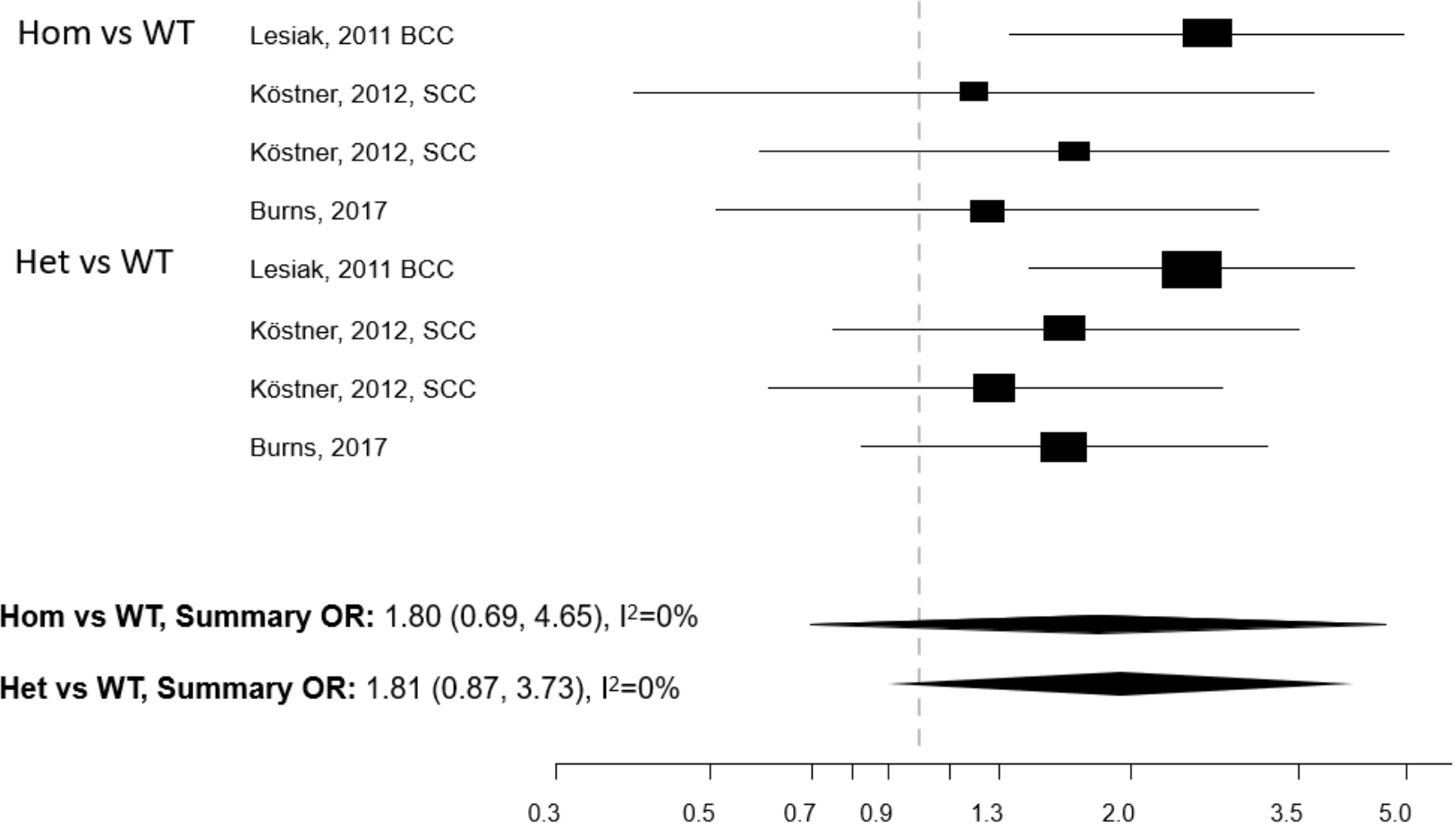

Figure 5. Forest plot for the association between the Taq1 polymorphism of the vitamin D receptor (VDR) gene and the risk of non-melanoma skin cancer. BCC: basal cell cancer. SCC: squamous cell cancer. RR: relative risk. Hom: homozygous. Het: heterozygous. WT: wild-type.

Finally, we found a single study that considered polymorphisms in the VDBP gene and NMSC risk [33]. The study relied on 7983 participants, of which 235 developed BCC during follow-up. BCC was not associated with the two polymorphisms of the VDBP gene (rs7041 and $r s 4588$ ) that were investigated, despite some limited evidence of an age-specific effect.

\section{Discussion}

We conducted a systematic literature review of studies that examined whether NMSC risk was associated with vitamin D serum or plasma concentration, vitamin D intake (from diet or supplements), or polymorphisms at the VDR or VDBP genes. We included 24 papers published between 2010 and 2020. There was some evidence that individuals with higher measured plasma or serum $25(\mathrm{OH}) \mathrm{D}$ concentration were at increased NMSC risk. However, studies were greatly heterogeneous, which suggests caution in drawing conclusions, particularly regarding the magnitude of the possible association. Vitamin D intake was associated with a mild increase in BCC risk in the large observational study by Park et al.; however, this finding was not confirmed in another four studies, two of which had a RCT design. Finally, NMSC risk was not associated with any single polymorphism of the $V D R$ or $V D B P$ genes.

The association between serum/plasma $25(\mathrm{OH}) \mathrm{D}$ concentration and NMSC risk is most likely due to UV radiation exposure being causally linked to both vitamin D concentration in the blood and NMSC risk. The mild, yet significantly increased BCC risk observed among individuals with higher vitamin D intake in the large study by Park et al. is difficult to explain, particularly in light of the growing evidence in favour of a protective effect played by vitamin $\mathrm{D}$ supplementation against cancer at several body sites [34-36]. However, the finding by Park et al. was mild, limited to BCC, and not confirmed in any other study, including two vitamin D supplementation RCTs which, because of their experimental design, are expected to be less susceptible to biases (e.g., confounding and misclassification) affecting observational studies. By and large, a strong association between vitamin D intake or supplementation and NMSC risk seems unlikely, and vitamin 
D supplementation should continue to be considered as an effective and reasonably safe method of achieving the recommended amount of vitamin D.

Individuals carrying polymorphisms at the VDR or VDBP genes do not seem to suffer from an increased NMSC risk based on the results of the present meta-analysis, with the possible exception of the VDR TaqI gene polymorphism. However, the number of studies eligible for inclusion in each gene polymorphism-specific meta-analysis model was limited, which prevents drawing firm conclusions. The studied polymorphisms of the VDR gene are known to impair the functionality of the receptor and eventually disrupt several vitamin D-linked biological pathways [8]. Considering that VDR polymorphisms may affect the risk of cancer at multiple body sites [37] and that an effect on NMSC risk cannot be ruled out a priori, we recommend that more studies are conducted in this research area.

This is the first systematic review and meta-analysis that simultaneously considered the link between vitamin $\mathrm{D}$ intake and blood concentration and the presence of polymorphisms at the VDR and VDBP gene with NMSC risk, thus allowing us to obtain a comprehensive picture of all the existing scientific literature on the topic. Despite this unprecedented breadth in its aims, the present work is not without some of the limitations that also flawed previously published systematic reviews and meta-analysis [34,38], including the limited number of papers eligible for some of the studied associations (meaning that there was not sufficient statistical power to run analyses stratified by NMSC subtype), the large heterogeneity in several study characteristics, and the lack of studies performing repeated measurements of vitamin D intake and blood concentration. Having limited the literature search to two scientific databases (PubMed and EMBASE), we cannot rule out to have missed a few eligible papers; however, we conducted a careful scan of the reference lists of previously published reviews and meta-analyses, and an extensive backward citation chaining of included papers, thus we believe it plausible that our literature searched succeeded in identifying most, if not all, existing eligible papers. An additional literature search covering the period from 4 February and 31 July was conducted during the peer-review process of the present paper, which identified, however, no further eligible papers. This reassures us that our review and meta-analysis is an up-to-date summary of the existing literature on the topic.

\section{Materials and Methods}

\subsection{Literature Search and Papers Selection}

The present literature search and quantitative meta-analysis was planned, conducted and reported according to the MOOSE guidelines [39]. On 3 February 2021, we searched the PubMed and EMBASE database using the following search string: 'vitamin D' AND (nonmelanoma OR 'non melanoma' OR 'basal cell ${ }^{* \prime}$ OR basalioma OR 'squamous cell ${ }^{* \prime}$ OR 'skin cancer' OR skin carcinoma*' OR keratinocyte), with the aim to ensure high sensitivity while looking for papers in which the exposure was any of vitamin D blood (serum or plasma) concentration, vitamin D intake (from diet and/or supplements), or polymorphisms in the vitamin $\mathrm{D}$ receptor $(V D R)$ or in the vitamin $\mathrm{D}$ binding protein $(V D B P)$ genes. A first screening of all retrieved items was conducted by discarding those papers that were deemed as surely not eligible for inclusion based on their title (e.g., papers reporting on malignancies other than NMSC, or papers focusing on cancer survival instead of on cancer risk). All papers that were not discarded during this initial screening were read in full to check if they met all the following inclusion criteria: studies with a case-control (CC), nested case-control (NCC), cohort, or randomised clinical trial (RCT) design that reported (or provided sufficient information-in the text, tables, or figures-to allow calculating) a measure of relative risk (RR) and 95\% confidence intervals (CI) or another measure of statistical uncertainty for the association between at least one exposure of interest (vitamin $\mathrm{D}$ blood concentration or dietary intake, use of vitamin D-containing supplements, and polymorphisms of the $V D R$ and $V D B P$ genes) and the risk of developing NMSC as a whole or either of its main subtypes (BCC and SCC). Risk estimates assessing the association between VDR polymorphisms and cancer risk comparing heterozygous carriers (Het) and 
homozygous carriers (Hom) with wild-type (WT) subjects were retrieved from all included studies. The corresponding authors of potentially eligible articles were contacted twice when deemed necessary, e.g., in order to obtain additional data or to ensure that the study really met all inclusion criteria (the article was discarded if no reply was received after the second attempt). The reference lists of all eligible papers as well as previously published reviews and meta-analyses were inspected to find additional publications. When there were two or more articles relying on fully or partially overlapping study populations, data were extracted from that with the largest study size. No language restriction was applied as long as an abstract was available in English. Two members of the writing group (SC and SR) independently decided on the inclusion of each paper, and any disagreement was resolved by consensus. The protocol of the present review was not registered; all the material prepared in the process of planning, literature search and articles selection, data extraction, data analysis, and text writing, is available from the corresponding author on reasonable request.

\subsection{Data Extraction and Statistical Analysis}

The following information was extracted from each eligible article: publication year, country of study, study design, source and number of study participants, number of NMSC cases (overall and by subtype), sex and age distribution, follow-up length, details of matching (if any was applied) in CC studies, procedures and methods used to assess the exposure, and what variables were used for statistical adjustment of RR estimates.

RR estimates and corresponding 95\% CI were transformed into logRR and corresponding variance using the formula proposed by Greenland [40]. When no RR estimate was provided, unadjusted OR and 95\% CI were calculated from tabular data. The distinction between the different ways to estimate a RR (e.g., odds ratio and hazard ratio) was ignored based on the rare disease assumption.

We used random effects models with maximum likelihood estimation (PROC MIXED in SAS software), taking into account between-study and within-study variability when more than one estimate from a single study was used, to calculate summary RR. Homogeneity of effects across studies was quantified by $\mathrm{I}^{2}$, which represents the percentage of total variation across studies that is attributable to heterogeneity rather than chance [41]. A funnel-plot-based approach was used for assessing publication bias evaluating regression of $\log (\mathrm{OR})$ on the sample size, weighted by the inverse of the variance [42].

To assess the influence of possible sources of bias, we considered the STROBE (Strengthening the Reporting of Observational Studies in Epidemiology) checklist proposed for observational epidemiologic studies [43]. According to the STROBE checklist, using metaregression, we evaluated factors influencing between-study heterogeneity. Leave-one-out sensitivity analysis was carried out to evaluate whether results were influenced by single studies. The quality assessment of included studies was conducted using the NewcastleOttawa scale (NOS) and the RoB 2 tools for observational studies (cohort, case-control and nested case-control studies) and randomized trials, respectively $[44,45]$.

All the statistical analyses were conducted using using SAS software (SAS Institute Inc., Cary, NC; version 9.2) and R software, version 2.12.2 (http:/ / www.r-project.org). The statistical significance threshold was set at $p=0.05$, and all tests were two-sided.

\section{Conclusions}

This systematic review and meta-analysis suggests that a strong link between vitamin D metabolism per se and NMSC risk is unlikely to exist, although some findings (in particular, the positive association between vitamin $\mathrm{D}$ intake from diet and supplements and $\mathrm{BCC}$ risk reported in a large observational study) are worthy of further investigation, for instance within existing large-scale RCTs including vitamin D supplementation as an experimental arm. The cornerstone of NMSC prevention must remain limiting exposure of the skin to UV light, and vitamin D supplementation may be recommended as the preferred method to secure the multiple health benefits of adequate vitamin D concentration 
(which extends far beyond the possible effects on the skin) while avoiding the health risks associated with an excessive exposure of the skin to the UV radiation.

Supplementary Materials: The following are available online at https:/ / www.mdpi.com/article/10 .3390 / cancers13194815/s1, File S1: Quality assessment of studies included in the systematic review and meta-analysis.

Author Contributions: Conceptualization, S.C., P.G., B.B., S.R. and S.G.; Methodology, S.C., P.G., F.B., S.R. and S.G.; Software, F.B., S.R. and S.G.; Validation, P.G., I.S., E.C., P.Q., C.S., S.R. and S.G.; Formal Analysis, F.B., S.R. and S.G.; Investigation, S.C., P.G., F.B., E.C., P.Q., B.B., C.S., S.R. and S.G.; Resources, I.S., C.S., S.R. and S.G.; Data Curation, S.C., F.B., B.B., and S.G.; Writing-Original Draft Preparation, S.C., P.G., and B.B.; Writing-Review \& Editing, I.S., F.B., E.C., P.Q., C.S., S.R. and S.G.; Visualization, S.C., F.B., S.R. and S.G.; Supervision, I.S., E.C., P.Q., C.S., and S.G.; Project Administration, F.B., B.B., and S.R.; Funding Acquisition, S.R. and S.G. All authors have read and agreed to the published version of the manuscript.

Funding: The European Institute of Oncology, Milan, Italy is partially supported by the Italian Ministry of Health with Ricerca Corrente and $5 \times 1000$ funds.

Institutional Review Board Statement: Not applicable.

Informed Consent Statement: Not applicable.

Data Availability Statement: No new data were created or analyzed in this study. Data sharing is not applicable to this article.

Acknowledgments: Federica Bellerba is a Ph.D. student within the European School of Molecular Medicine (SEMM). IMI includes the following members of the Scientific Board to be considered as co-authors: Ignazio Stanganelli (Meldola and Parma, Italy), Daniela Massi (Firenze, Italy), Pietro Quaglino (Torino, Italy), Corrado Caracò (Napoli, Italy), Virginia Ferraresi (Roma, Italy), Antonio M. Grimaldi (Benevento, Italy), Roberto Patuzzo (Milano, Italy), Giuseppe Palmieri (Sassari, Italy), Mario Mandalà (Perugia, Italy), Paola Queirolo (Milano, Italy).

Conflicts of Interest: The Authors declare no conflicts of interest.

\section{References}

1. Apalla, Z.; Lallas, A.; Sotiriou, E.; Lazaridou, E.; Ioannides, D. Epidemiological trends in skin cancer. Dermatol. Pract. Concept. 2017, 7, 1-6. [CrossRef]

2. Mudigonda, T.; Pearce, D.J.; Yentzer, B.A.; Williford, P.; Feldman, S.R. The economic impact of non-melanoma skin cancer: A review. J. Natl. Compr. Cancer Netw. 2010, 8, 888-896. [CrossRef]

3. Savoye, I.; Olsen, C.M.; Whiteman, D.C.; Bijon, A.; Wald, L.; Dartois, L.; Clavel-Chapelon, F.; Boutron-Ruault, M.C.; Kvaskoff, M. Patterns of Ultraviolet Radiation Exposure and Skin Cancer Risk: The E3N-SunExp Study. J. Epidemiol. 2018, 28, 27-33. [CrossRef] [PubMed]

4. Belbasis, L.; Stefanaki, I.; Stratigos, A.J.; Evangelou, E. Non-genetic risk factors for cutaneous melanoma and keratinocyte skin cancers: An umbrella review of meta-analyses. J. Dermatol. Sci. 2016, 84, 330-339. [CrossRef] [PubMed]

5. Gandini, S.; Palli, D.; Spadola, G.; Bendinelli, B.; Cocorocchio, E.; Stanganelli, I.; Miligi, L.; Masala, G.; Caini, S. Anti-hypertensive drugs and skin cancer risk: A review of the literature and meta-analysis. Crit. Rev. Oncol. Hematol. 2018, 122, 1-9. [CrossRef]

6. Dominguez, L.J.; Farruggia, M.; Veronese, N.; Barbagallo, M. Vitamin D Sources, Metabolism, and Deficiency: Available Compounds and Guidelines for Its Treatment. Metabolites 2021, 11, 255. [CrossRef] [PubMed]

7. Bikle, D.D. Vitamin D and bone. Curr. Osteoporos. Rep. 2012, 10, 151-159. [CrossRef] [PubMed]

8. Khammissa, R.A.G.; Fourie, J.; Motswaledi, M.H.; Ballyram, R.; Lemmer, J.; Feller, L. The Biological Activities of Vitamin D and Its Receptor in Relation to Calcium and Bone Homeostasis, Cancer, Immune and Cardiovascular Systems, Skin Biology, and Oral Health. Biomed. Res. Int. 2018, 2018, 9276380. [CrossRef]

9. Toner, C.D.; Davis, C.D.; Milner, J.A. The vitamin D and cancer conundrum: Aiming at a moving target. J. Am. Diet. Assoc. 2010, 110, 1492-1500. [CrossRef]

10. Asgari, M.M.; Tang, J.; Warton, M.E.; Chren, M.M.; Quesenberry, C.P., Jr.; Bikle, D.; Horst, R.L.; Orentreich, N.; Vogelman, J.H.; Friedman, G.D. Association of prediagnostic serum vitamin D levels with the development of basal cell carcinoma. J. Invest. Dermatol. 2010, 130, 1438-1443. [CrossRef] [PubMed]

11. Tang, J.Y.; Parimi, N.; Wu, A.; Boscardin, W.J.; Shikany, J.M.; Chren, M.M.; Cummings, S.R.; Epstein, E.H., Jr.; Bauer, D.C.; Osteoporotic Fractures in Men (MrOS) Study Group. Inverse association between serum 25(OH) vitamin D levels and nonmelanoma skin cancer in elderly men. Cancer Causes Control 2010, 21, 387-391. [CrossRef] 
12. Eide, M.J.; Johnson, D.A.; Jacobsen, G.R.; Krajenta, R.J.; Rao, D.S.; Lim, H.W.; Johnson, C.C. Vitamin D and nonmelanoma skin cancer in a health maintenance organization cohort. Arch. Dermatol. 2011, 147, 1379-1384. [CrossRef] [PubMed]

13. Lesiak, A.; Norval, M.; Wodz-Naskiewicz, K.; Pawliczak, R.; Rogowski-Tylman, M.; Sysa-Jedrzejowska, A.; Sobjanek, M.; Wlodarkiewicz, A.; Narbutt, J. An enhanced risk of basal cell carcinoma is associated with particular polymorphisms in the VDR and MTHFR genes. Exp. Dermatol. 2011, 20, 800-804. [CrossRef] [PubMed]

14. Liang, G.; Nan, H.; Qureshi, A.A.; Han, J. Pre-diagnostic plasma 25-hydroxyvitamin D levels and risk of non-melanoma skin cancer in women. PLoS ONE 2012, 7, e35211. [CrossRef] [PubMed]

15. Van der Pols, J.C.; Russell, A.; Bauer, U.; Neale, R.E.; Kimlin, M.G.; Green, A.C. Vitamin D status and skin cancer risk independent of time outdoors: 11-year prospective study in an Australian community. J. Invest. Dermatol. 2013, 133, 637-641. [CrossRef] [PubMed]

16. Skaaby, T.; Husemoen, L.L.; Thuesen, B.H.; Pisinger, C.; Jørgensen, T.; Roswall, N.; Larsen, S.C.; Linneberg, A. Prospective population-based study of the association between serum 25-hydroxyvitamin-D levels and the incidence of specific types of cancer. Cancer. Epidemiol. Biomarkers. Prev. 2014, 23, 1220-1229. [CrossRef]

17. Soares, A.M.; Szejnfeld, V.L.; Enokihara, M.Y.; Michalany, N.; Castro, C.H. High serum 25-hydroxyvitamin D concentration in patients with a recent diagnosis of non-melanoma skin cancer: A case-control study. Eur. J. Dermatol. 2018, 28, 649-653.

18. Winsløw, U.C.; Nordestgaard, B.G.; Afzal, S. High plasma 25-hydroxyvitamin D and high risk of nonmelanoma skin cancer: A Mendelian randomization study of 97849 individuals. Br. J. Dermatol. 2018, 178, 1388-1395. [CrossRef]

19. Skelsey, M.; Janicic, N.; Mendu, R.; Moshell, A.; Colombo, M.; Soldin, S. Hypovitaminosis D and non-melanoma skin cancer. Conference: Annual Meeting of the Society for Investigative Dermatology. Atlanta, Georgia, 5-8 May 2010. J. Invest. Dermatol. 2010, 130, S25.

20. De Gruijl, F.R.; Wolterbeek, R.; Pavel, S.; de Fijter, J.W.; Hamdy, N.A.T.; Bouwes Bavinck, J.N. Low wintertime pre-diagnostic vitamin D status is associated with an increased risk of internal malignancies in kidney transplant recipients. Photochem. Photobiol. Sci. 2018, 17, 1946-1955. [CrossRef]

21. Mansoor, E.; Maruggi, C.; Saleh, M.A.; Sinh, P.; Dave, M.; Bordeaux, J.; Cooper, G.S.; Katz, J. Epidemiology and Risk Factors of Malignant Melanoma, Squamous Cell Carcinoma and Basal Cell Carcinoma of the Skin in Crohn's Disease in the United States Between 2012 and 2017: A Population Based Study. Gastroenterology 2018, 154, S-601-S-602. [CrossRef]

22. Hosseini, M.S.; Salarvand, F.; Ehsani, A.H.; Noormohammadpour, P.; Azizzadeh, S.; Mousavi, M.; Morsali, M. Relationship Between Level of Serum 25-Hydroxyvitamin D and Risk of Squamous Cell Carcinoma in an Iranian Population. Dermatol. Pract. Concept. 2019, 9, 278-282. [CrossRef] [PubMed]

23. Vojdeman, F.J.; Madsen, C.M.; Frederiksen, K.; Durup, D.; Olsen, A.; Hansen, L.; Heegaard, A.M.; Lind, B.; Tjønneland, A.; Jørgensen, H.L.; et al. Vitamin D levels and cancer incidence in 217,244 individuals from primary health care in Denmark. Int. J. Cancer. 2019, 145, 338-346. [CrossRef] [PubMed]

24. Davies, T.W.; Treasure, F.P.; Welch, A.A.; Day, N.E. Diet and basal cell skin cancer: Results from the EPIC-Norfolk cohort. Br. J. Dermatol. 2002, 146, 1017-1022. [CrossRef] [PubMed]

25. Asgari, M.M.; Chren, M.M.; Warton, E.M.; Friedman, G.D.; White, E. Supplement use and risk of cutaneous squamous cell carcinoma. J. Am. Acad. Dermatol. 2011, 65, 1145-1151. [CrossRef]

26. Tang, J.Y.; Fu, T.; Leblanc, E.; Manson, J.E.; Feldman, D.; Linos, E.; Vitolins, M.Z.; Zeitouni, N.C.; Larson, J.; Stefanick, M.L. Calcium plus vitamin D supplementation and the risk of nonmelanoma and melanoma skin cancer: Post hoc analyses of the women's health initiative randomized controlled trial. J. Clin. Oncol. 2011, 29, 3078-3084. [CrossRef]

27. Park, S.M.; Li, T.; Wu, S.; Li, W.Q.; Qureshi, A.A.; Cho, E. Vitamin D Intake and Risk of Skin Cancer in US Women and Men. PLoS ONE 2016, 11, e0160308. [CrossRef]

28. Passarelli, M.N.; Karagas, M.R.; Mott, L.A.; Rees, J.R.; Barry, E.L.; Baron, J.A. Risk of keratinocyte carcinomas with vitamin D and calcium supplementation: A secondary analysis of a randomized clinical trial. Am. J. Clin. Nutr. 2020, 112, 1532-1539. [CrossRef]

29. Burns, E.M.; Guroji, P.; Ahmad, I.; Nasr, H.M.; Wang, Y.; Tamimi, I.A.; Stiefel, E.; Abdelgawwad, M.S.; Shaheen, A.; Muzaffar, A.F.; et al. Association of Vitamin D Receptor Polymorphisms With the Risk of Nonmelanoma Skin Cancer in Adults. JAMA Dermatol. 2017, 153, 983-989. [CrossRef]

30. Han, J.; Colditz, G.A.; Hunter, D.J. Polymorphisms in the MTHFR and VDR genes and skin cancer risk. Carcinogenesis 2007, 28, 390-397. [CrossRef]

31. Köstner, K.; Denzer, N.; Koreng, M.; Reichrath, S.; Gräber, S.; Klein, R.; Tilgen, W.; Vogt, T.; Reichrath, J. Association of genetic variants of the vitamin D receptor (VDR) with cutaneous squamous cell carcinomas (SCC) and basal cell carcinomas (BCC): A pilot study in a German population. Anticancer. Res. 2012, 32, 327-333. [PubMed]

32. Morgado-Águila, C.; Rey-Sánchez, P.; Gil-Fernández, G.; Costa-Fernández, M.C.; Rodríguez-Velasco, F.J. Vitamin D Receptor Polymorphisms and Non-Melanoma Skin Cancer Risk: A Case-Control Study. J. Clin. Med. 2020, 9, 3819. [CrossRef] [PubMed]

33. Flohil, S.C.; de Vries, E.; van Meurs, J.B.; Fang, Y.; Stricker, B.H.; Uitterlinden, A.G.; Nijsten, T. Vitamin D-binding protein polymorphisms are not associated with development of (multiple) basal cell carcinomas. Exp. Dermatol. 2010, 19, 1103-1105. [CrossRef]

34. Zhang, X.; Niu, W. Meta-analysis of randomized controlled trials on vitamin D supplement and cancer incidence and mortality. Biosci. Rep. 2019, 39, BSR20190369. [CrossRef] [PubMed] 
35. Boughanem, H.; Canudas, S.; Hernandez-Alonso, P.; Becerra-Tomás, N.; Babio, N.; Salas-Salvadó, J.; Macias-Gonzalez, M. Vitamin D Intake and the Risk of Colorectal Cancer: An Updated Meta-Analysis and Systematic Review of Case-Control and Prospective Cohort Studies. Cancers 2021, 13, 2814. [CrossRef] [PubMed]

36. Sun, K.; Zuo, M.; Zhang, Q.; Wang, K.; Huang, D.; Zhang, H. Anti-Tumor Effect of Vitamin D Combined with Calcium on Lung Cancer: A Systematic Review and Meta-Analysis. Nutr. Cancer 2020, 1-10. [CrossRef] [PubMed]

37. Gnagnarella, P.; Raimondi, S.; Aristarco, V.; Johansson, H.; Bellerba, F.; Corso, F.; De Angelis, S.P.; Belloni, P.; Caini, S.; Gandini, S. Ethnicity as modifier of risk for Vitamin D receptors polymorphisms: Comprehensive meta-analysis of all cancer sites. Crit. Rev. Oncol. Hematol. 2021, 158, 103202. [CrossRef] [PubMed]

38. Mahamat-Saleh, Y.; Aune, D.; Schlesinger, S. 25-Hydroxyvitamin D status, vitamin D intake, and skin cancer risk: A systematic review and dose-response meta-analysis of prospective studies. Sci. Rep. 2020, 10, 13151. [CrossRef]

39. Stroup, D.F.; Berlin, J.A.; Morton, S.C.; Olkin, I.; Williamson, G.D.; Rennie, D.; Moher, D.; Becker, B.J.; Sipe, T.A.; Thacker, S.B. Meta-analysis of observational studies in epidemiology: A proposal for reporting. Meta-analysis of Observational Studies in Epidemiology (MOOSE) group. JAMA 2000, 283, 2008-2012. [CrossRef]

40. Greenland, S. Quantitative methods in the review of epidemiologic literature. Epidemiol. Rev. 1987, 9, 1-30. [CrossRef]

41. Higgins, J.P.; Thompson, S.G. Quantifying heterogeneity in a meta-analysis. Stat. Med. 2002, 21, 1539-1558. [CrossRef] [PubMed]

42. Macaskill, P.; Walter, S.D.; Irwig, L. A comparison of methods to detect publication bias in meta-analysis. Stat. Med. 2001, 20, 641-654. [CrossRef] [PubMed]

43. Von Elm, E.; Altman, D.G.; Egger, M.; Pocock, S.J.; Gøtzsche, P.C.; Vandenbroucke, J.P.; STROBE Initiative. The Strengthening the Reporting of Observational Studies in Epidemiology (STROBE) statement: Guidelines for reporting observational studies. J. Clin. Epidemiol. 2008, 61, 344-349. [CrossRef] [PubMed]

44. The Newcastle-Ottawa Scale (NOS) for Assessing the Quality of Nonrandomised Studies in Meta-Analyses. Available online: http:/ / www.ohri.ca/programs/clinical_epidemiology/oxford.asp (accessed on 12 June 2021).

45. RoB 2 Tool. A Revised Cochrane Risk of Bias Tool for Randomized Trials. Available online: https://www.riskofbias.info/ welcome/rob-2-0-tool (accessed on 12 June 2021). 